\title{
SOURCES OF FINANCING PUBLIC GOODS IN POLISH AGRICULTURE
}

\author{
BARBARA ROSZKOWSKA-MĄDRA ${ }^{1}$, ELŻBIETA ZALESKO
}

\begin{abstract}
The purpose of this paper is to indicate the scope of public intervention measures (Rural Development Program Funds) contributing to the fulfillment of the agricultural sector, which is an important sector of the Polish economy, not only for production but also for non-productive functions in the form of public goods and services, increasingly perceived and appreciated by the public. This constitutes a strong foundation for their support and is considered as a form of remuneration for farmers to generate positive externalities (public goods) provided to the society for which creation, the market does not reward the agricultural producers. The analyzes carried out show that, under the Common Agricultural Policy, rural development policy offers a number of measures to support the agricultural economy, agricultural practices and other investments thus contributing to the generation of public goods in agriculture. These measures support the development of rural areas and encourage the creation of public goods, both of an environmental and social nature.
\end{abstract}

\section{Keywords}

Agriculture; public goods; public spending; European model of agriculture; Common Agricultural Policy

\section{JEL Classification: H41, H72, P32}

1 Doctor habilitated in Economics, the professor at the University of Bialystok, Faculty of Economics and Management, Poland. The Author specializes in the issues of balanced and multifunctional development of agriculture and rural areas, as well as the influence of the state and community policies on rural development and agriculture. The Author of nearly 80 publications on the national and international scale. Contact e-mail: broszkowska@poczta.onet.pl.

2 Doctor of Economics, University of Bialystok, Poland, Faculty of Economics and Informatics in Vilnius (Lithuania). The Author of publications on macroeconomic issues (foreign trade, foreign investments, and competitiveness of the economy) and agri-food market. Contact email: ezalesko@gmail.com. 


\section{Introduction}

The sectors of the modern economy reached by public spending made in the public interest include agriculture. It is developing in rural areas comprising $80 \%$ of the European territory and as much as $93 \%$ of the Polish territory. Activities conducted as a part of agricultural activity result in the generation of private and public goods. Provision of private goods is regulated by the market, unlike public goods, in case of which the market mechanism fails, being unable to develop markets which would enable ensuring payments for the provision of such goods. Lack of compensation for provision of public goods by agriculture may result in a decline in satisfaction of needs of the entire society which wishes to live and enjoy a beautiful landscape with a high degree of biodiversity; it may also lead to degradation of certain resources the maintenance of which in agriculture is economically substantiated (Czyżewski, Kułyk, 2011: 16-25). Therefore, it is very important to support creation thereof through public intervention in the form of appropriate activities capable of ensuring a sufficient level of generation of public goods to match the social needs. This will enable implementation of the idea of sustainable agriculture and rural areas, serving as a base for the modern European agriculture model (EAM), consisting, above all, in: (Roszkowska-Mądra, 2010: 35): dissemination of the idea of sustained development, ascribing essential importance to multi-functionality enabling agriculture to enter the path of sustained development; departure from the market-type agricultural policy in favors of support to multifunctional rural development detached from ongoing production; financing of positive external effects of agriculture; transition from sector-type agricultural policy to integrated agricultural and rural development policy; an increase in appreciation of the role of human capital, social capital and institutions in agricultural and rural development, in line with the concept of endogenous development.

The goal of the present study is to indicate the scope of the applied public intervention measures (the measures of the rural development program) in Poland and assorted countries of the European Union, contributing to performance by the agricultural sector of not only production functions but also of non-production ones in the form of public goods and services, increasingly noticed and appreciated by societies.

\section{Agriculture as Source of Public Goods}

Public goods are a category of market failure; they are goods desired by the society, unable to be provided by the market mechanism. Under the traditional approach, the term "public good" refers to goods which are generally available and nobody 
is excluded from the benefits resulting from use thereof (lack of exclusion from consumption) (Czyżewski, Kułyk, 2011: 16-25). Due to these characteristics, it is difficult to receive payment for the provision of these goods, causing, in turn, that there are no incentives to provide them (Małażewska, 2015: 132-147). P. Samuelson was the first to write on public goods in 1954, and his article is regarded as the foundation of the modern theory of public goods (Samuelson, 1954: 387-389).

The development of interest in public goods in agriculture has been largely caused by the concept of sustained development, being a peculiar antidote to the emergence of numerous restrictions and hazards for further development of agricultural, connected with farming according to the industrial formula accompanied with the predominant focus on the implementation of the production function. Today, the accepted model is developed in line with the concept of sustained development, and multi-functionality of agriculture plays a special role in its nature. It is regarded as the most important guarantee of implementation of the concept of sustained agricultural and rural development. Its role with regard to economy, environment, and society, as well as the preservation of the rural heritage and ensuring of fair income for farmers, is special. The notion of multi-functionality in relation to the agricultural sector means performance by agriculture of not just the production functions but the non-production ones in the form of public goods and services, increasingly noticed and appreciated by modern societies, both domestically and internationally, providing a strong base substantiating support thereof (Wilkin, 2008: 9-20; Marsden, Sonnino, 2009: 422-431; Renting, Rossini, Groot, Van der Ploeg, Laurent, Perraud, Stobbelaar, Van Ittersum, 2009: 112-123).

The provision of public goods by agriculture is treated as one of agriculture's functions (Liziński, 2012: 146-163). Goods provided by agriculture are of special nature, as their availability depends on both natural conditions and human activity. They often have the character of external effects of agricultural production processes. Therefore, activities undertaken by farmers and the applied practices with regard to manufacturing techniques may result in a contribution to an increase in availability of public goods or limit their value in case of overexploitation (Małażewska, Gajos, 2016: 158-163). The demand for these goods results from the expectations of the entire society which wishes to enjoy such things as beautiful landscapes with a high degree of biodiversity (Cooper, Hart, Baldock, 2009: 14-29).

The main public goods provided by agriculture include (Europejska Sieć na rzecz Rozwoju Obszarów Wiejskich, 2010; Cooper, Hart, Baldock, 2009: 14-29):

- biological diversity of agricultural areas;

- water quality and availability;

- soil functionality; 
- air quality;

- climate stability;

- resistance to floods and fires;

- agricultural landscapes;

- the vitality of rural areas;

- welfare and health of farm animals;

- food safety;

- alternative modes of supply.

The Thematic Working Group "Public Goods" (European Network for Rural Development, 2009) has distinguished two basic types of public goods generated by agriculture, namely, environmental and social ones. The environmental goods include agricultural landscape, biodiversity of agricultural land, water quality and availability, soil functionality, climate stability, air quality, resistance to floods and fires. The social goods include vitality of rural areas, food safety, and security, as well as welfare and health of animals (Małażewska, 2016: 138). A different approach to the classification of public goods in agriculture has been presented in the Study for the European Parliament, dividing public goods into five groups: environmental (including biodiversity of agricultural land, water quality and availability, soil functionality, air quality), agricultural landscapes, cultural values, vitality of rural areas, welfare of farm animals, and food safety and security (Dyrekcja Generalna do Spraw Polityki Wewnętrznej, 2011).

The scale of occurrence of goods may be local or global. The extent of usage thereof by the society (availability) may be very diverse as well. The extent of public availability of goods is determined by the maximum number of people able to consume the given good. Due to the very wide diversity of public goods generated in agriculture, both in terms of their scale of occurrence and their availability, the Authors of the report for the Institute for European Environmental Policy and Duer have identified degrees of their public availability, as presented in Table 1. Private goods are characterized by the fact they exclude non-owners from consumption. Public goods, on the other hand, have varying degrees of availability - average or high (common).

Biological diversity of agricultural areas is regarded as the most important public good depending on agriculture; its existence and stability is an effect of the applied agricultural practices generating diverse external effects (positive or negative). External effects, both positive and negative, occur when a part of costs or benefits of actions of one person is transferred to others without an appropriate compensation (Duer, 2010: 87). Generation of public goods in agriculture is connected with 
bearing of certain costs for which farmers are not compensated by the market. Therefore, it is necessary to implement appropriate programme activities as incentives for farmers to generate them, although not all farmer activities connected with provision of an appropriate level of public goods require support using financial resources in a public intervention. According to the "polluter pays" principle, farmers receive no compensation for actions they are obliged to perform within the framework of the legal requirements in force or other binding standards - they are supposed to bear the related costs themselves. However, observation of the legal requirements in force is a prerequisite for receiving of various payments resulting from the common agricultural policy. e.g. observance of essential principles and standards protecting the environment and landscape of rural areas, contained in the principle of cross-compliance, conditions collection of direct payments and subsidies due to farming in less-favored areas (LFAs). However, observance of these principles only secures generation of public goods in agriculture to a basic extent. It is only voluntary declaration by a farmer to provide and maintain public goods available to the entire society, going beyond the fulfillment of the cross-compliance principle, Authorizes the given farmer to receive an additional bonus in the name of the "provider gets" principle. Therefore, on the part of the state, this requires application of appropriate financial incentives for farmers to generate public goods the creation of which would otherwise have no sense to them from the economic viewpoint. Rewarding of farmers for provision of public goods should take place on the level on which such goods are made available to the society. For instance, protection of biodiversity (genetic, species, ecosystems), water protection, ensuring of food security, prevention of climate changes are all public goods of global nature, with high availability to the society, therefore they should be rewarded according to a uniform system for all countries.

\section{Public Intervention Supporting Creation of Public Goods in Agriculture}

Under the Common Agricultural Policy, the rural development policy provides a range of measures supporting agricultural economy, agricultural practices and other investments, thus fostering generation of public goods in agriculture. These measures support rural development and encourage generation of public goods, both of environmental and social nature. Wilkin divides public goods provided by agriculture as follows (Wilkin, 2010: 17-24):

- environmental (biodiversity, agricultural landscape, soil preservation, appropriate water conditions);

- economic (food security, food safety, energetic safety); 
- socio-cultural (economic and social vitality of rural areas, enrichment of national culture, formation of local, regional and cultural identity).

Measures allocated for rural development, applied as incentives for generation of public goods, may be divided into the three main categories (Baldock, Hart, Schelle):

- area payments encouraging the application of farming practices beneficial to soils, water quality, species habitats, and landscape preservation;

- capital investments which may serve introduction of new, environmentally sustained techniques and technologies to farms, support to the creation of new activities of non-agricultural nature, both in and outside farms, as well as other activities in rural areas, such as preservation and promotion of cultural heritage, traditional social landscape and traditional way of life;

- investment in consulting and training for farmland managers as well as the building of potential of people in rural communities.

Table 1 Measures Applied under Rural Development Programme and Public Goods

\begin{tabular}{|c|c|c|}
\hline \multirow{3}{*}{ Kind of aid } & \multicolumn{2}{|c|}{ Public goods } \\
\hline & Environmental & Social \\
\hline & \multicolumn{2}{|c|}{ Measures applied in order to generate public goods } \\
\hline $\begin{array}{l}\text { Area payments due to } \\
\text { land management }\end{array}$ & $\begin{array}{l}\text { - agri-environmental; } \\
\text { - related to natural handicaps; } \\
\text { - related to the Natura } 2000 \text { network }\end{array}$ & $\begin{array}{l}\text { - agri-environmental; } \\
\text { - related to natural } \\
\text { - handicaps }\end{array}$ \\
\hline $\begin{array}{l}\text { Capital investments in } \\
\text { material infrastructure }\end{array}$ & $\begin{array}{l}\text { - non-production investments; } \\
\text { - modernization of farms; } \\
\text { - development of infrastructure; } \\
\text { - semi-subsistence farms; } \\
\text { - preservation and improvement of } \\
\text { the condition of rural heritage; } \\
\text { - the increase of the added value of } \\
\text { - agricultural products; } \\
\text { - diversification. }\end{array}$ & $\begin{array}{l}\text { - development of infrastructure; } \\
\text { - semi-subsistence farms; } \\
\text { - diversification of economic } \\
\text { activities; } \\
\text { - encouragement of tourism- } \\
\text { related activity; } \\
\text { - essential services for the } \\
\text { economy of the rural population; } \\
\text { - village renewal; } \\
\text { - leader approach. }\end{array}$ \\
\hline $\begin{array}{l}\text { Consulting, training, } \\
\text { and building of potential } \\
\text { serving reinforcement of } \\
\text { the human capital }\end{array}$ & - related to consulting and training. & $\begin{array}{l}\text { - training and transfer of } \\
\text { information; } \\
\text { - Leader approach. }\end{array}$ \\
\hline
\end{tabular}

Source: Own elaboration based on Baldock, Hart, Scheele, 2010.

Many agriculture-supporting resources also foster the simultaneous creation of goods of environmental, socio-cultural and economic nature. Member states of 
the European Union can freely select and allocate the resources as well as choose the kind of availability thereof in accordance with their specific nature and needs. Figure 1 shows the diversity of spending of resources by assorted member states of the European Union (depending on the needs and their specific nature) on individual axes in order to axis 1 (economic) - support the competitiveness of the agricultural and forest sector; axis 2 (environmental) - support sustained management of agricultural and forestry land resources; axis 3 (social) - economic diversification of rural areas and improvement of the quality of life in rural areas; axis 4 (Leader) - building of social capital.

\section{Figure 1 Allocation of financial resources to individual axes in the Rural Development Program for 2007-2013 (\%) in assorted European Union countries}

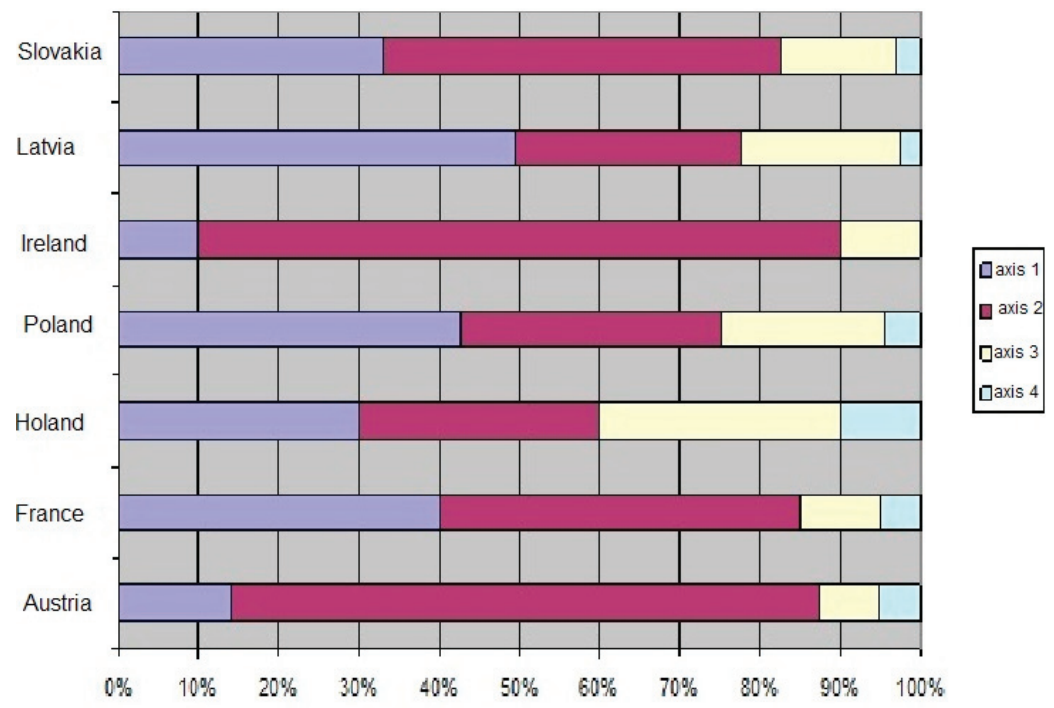

Source: Developed on the basis of RDP 2007-2013 of Assorted EU Countries.

In assorted countries, as illustrated in Figure 1, the structure of spending on individual axes of the RDP are diversified depending on the national specificity. Resources spent under Axis 3 comprise between 7.3\% in the RDP structure in Austria and 30\% in the Netherlands; those under Axis 2 comprise between $30 \%$ in the Netherlands and $80 \%$ in Ireland. The contribution of the EU in the financing of individual axes is diverse and co-financed from national, public and private sources. 
Figure 2 Structure of Expenditures in the EU Member States under Rural Areas Programme in 2007-2013

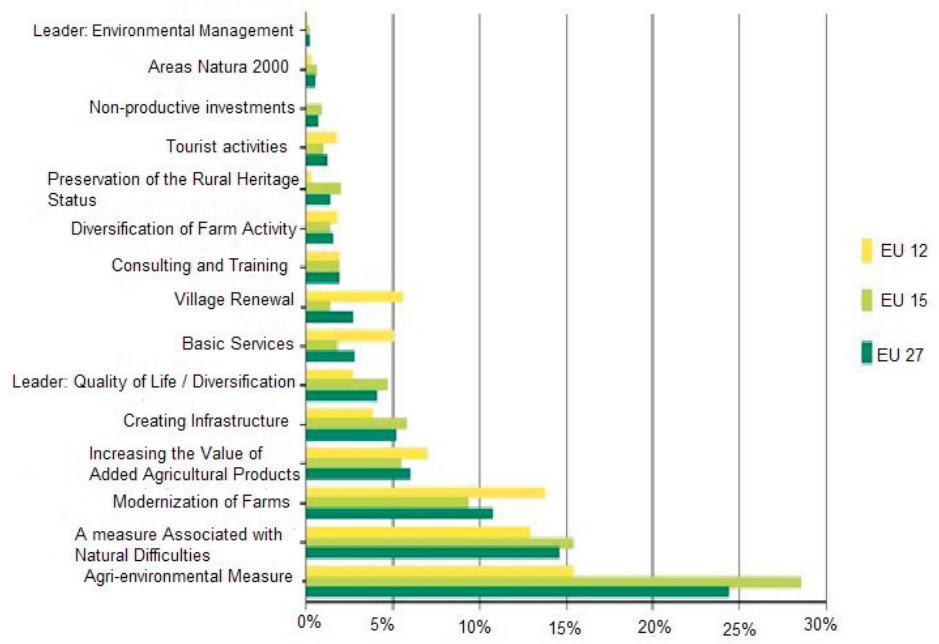

Source: Baldock, D., Hart, K., Scheele, M., 2010.

Analyzing the structure of expenditures under the rural development programmes for 2007-2013 in groups of countries (depending on the date of their accession to the EU), as presented in Figure 2, one can observe that almost a half of the budget for rural development is allocated for 3 resources: an agri-environmental measure, a measure connected with support to areas with farming handicaps, and a measure connected with modernization of farms. All these measures support activities favorable to the generation of public goods (environmental, socio-cultural and economic $\mathrm{c}^{3}$ ) in agriculture, although measures with a more direct focus on the provision of environmental public goods are usually included in Axis 2, whereas those with a more direct focus on the provision of social public goods are found within Axis 3. Therefore, interest on the programmed budget allocated to individual Axes of the RDP provides wide indications concerning the priority is given to individual objectives in different member states.

The European Union policy implemented after 2013 is still associated with the implementation of the so-called European agricultural model the main attributes of which include multi-functionality and sustainability. For Poland, the total amount of resources allocated for activities implemented under the Common Agricultural Policy between 2014 and 2020 is EUR 32.09 billion, including 23.49 billion designated for direct payments. The applied system of direct subsidies is 
favorable to the generation of public goods and connected with the observation of the requirements resulting from the implemented policy by subsidy beneficiaries. This applies, among other things, to greening payment depending on the fulfillment of requirements concerning diversification of crops, maintenance of permanent farmland, as well as the allocation of a part of the area for ecological purposes. 30\% of resources earmarked for direct subsidies were allocated for this purpose (System płatności bezpośrednich w latach 2015-2020, 2015).

The key activities in favor of the provision of environmental public goods include restoration and protection as well as enhancement of biological diversity and agriculture of high conservation value; improvement of water management (including fertilization and use of pesticides); prevention of soil erosion (BiernatJarka, 2016: 144-154). Generation of environmental public goods is also helped by the maintenance of use of farmland located in less-favorable areas, as well as the preservation of landscape advantages and biodiversity in these areas, and, consequently, of their socio-economic vitality. The natural environment is positively impacted by the use of sustainable farming methods, as well as activities in favor of protection of soils with high natural qualities. Ensuring of social public goods is possible through implementation of activities in the area of modernization and structural transformation of agriculture, which consequently enables ensuring of food security.

\section{Conclusions}

Activities implemented under the Common Agricultural Policy provide a wide range of instruments supporting generation of safe and high-quality food, protection of biodiversity and landscape, preservation of production capacities (especially of soils) for the purposes of future production, preservation of attractiveness and vitality of rural areas, production of goods which would be competitive on the global market, making an appropriate contribution to solution of the problem of food security, and halting of degradation of natural environment on a global scale (Zegar, 2010: 11-25).

Therefore, the Common Agricultural Policy should continue to strive to provide a wide array of instruments of rural development policy, efficiently supporting the generation of public goods in agriculture, such goods being expected by the modern European society. 


\section{References}

Adamowicz, M.: Wielofunkcyjne rolnictwo w rozwoju obszarów wiejskich (Multifunctional agriculture in rural development), in: Kłodziński, M., Dzun, W. (eds.): Rolnictwo a rozwój obszarów wiejskich (Agriculture and rural development), Warszawa: IRWiR PAN, 2005.

Baldock, D., Hart, K., Scheele, M.: Dobra publiczne i interwencja publiczna w rolnictwie (Public goods and public intervention in agriculture), Bruxelles: European Network for Rural Develpment, 2010.

Biernat-Jarka, A.: Dobra publiczne w rolnictwie w nowej perspektywie finansowej Unii Europejskiej (Public goods in agriculture in the new financial perspective of the European Union), Zagadnienia Ekonomiki Rolnej (Problems of Agricultural Economics) no. 1 (2016).

European Network for Rural Development: Conceptual Framework on Public Goods Provided Through Agriculture in the EU. Working Document of the Technical Working Group "Public Goods", 2009.

Cooper, T., Hart, K., Baldock, D.: Provision of Public Goods through Agriculture in the European Union. Rapport Prepared for DG Agriculture and Rural Development, London: Institute for European Environmental Policy, 2009.

Czudec, A.: Ekonomiczne uwarunkowania rozwoju wielofunkcyjnego rolnictwa (Economic conditions for the development of multifunctional agriculture), Rzeszów: Wydawnictwo Uniwersytetu Rzeszowskiego, 2009.

Czyżewski, A., Kułyk, P.: Dobra publiczne w koncepcji wielofunkcyjnego rozwoju rolnictwa; ujęcie teoretyczne i praktyczne, Problemy rolnictwa światowego (Public goods in the concept of multifunctional agricultural development; theoretical and practical approach, Problems of world agriculture), Zeszyty Naukowe SGGW w Warszawie (Scientific Works of SGGW in Warsaw) no. 2 (2011).

Czyżewski, B., Matuszczak, A.: Rola rent gruntowych w zrównoważonym rozwoju rolnictwa (The role of land rents in the sustainable development of agriculture) ACTA Scientiarum Polonorum, Oeconomia no. 3 (2010).

Daniel, F.J., Perraud D.: The Multifunctionality of Agriculture and Contractual Policies. A Comparative Analysis of France and the Netherlands, Journal of Environmental Management no. 90 (2009).

Duer, I.: Dobra publiczne użytkowane i dostarczane przez rolnictwo-wspierane w ramach programu rozwoju obszarów wiejskich (Public goods used and supplied by agriculture - supported under the rural development program), Studia i Raporty (Studies and Raports) no. 21 (2010).

Europejska Sieć na rzecz Rozwoju Obszarów Wiejskich: Dobra publiczne i publiczny system interwencji, Raport analityczny przekazany do członków TGR 3 (Public goods and public intervention system, Analytical report passed to TGR members 3), 2010.

Liziński, T.: Problemy wyceny dóbr i usług środowiskowych na obszarach wiejskich (Problems of valuation of environmental goods and services in rural areas), Zeszyty Naukowe Uniwersytetu Szczecińskiego. Ekonomiczne Problemy Usług (Scientific Works of University of Szczecin. Economic Problems of Servicies) no. 89 (2012). 
Małażewska, S., Gajos, E.: Hierarchia dóbr publicznych w rolnictwie (Hierarchy of public goods in agriculture), Roczniki Naukowe SERiA (Scientific Yearbook of SERiA) no. 5 (2016).

Małażewska, S.: Środowiskowe dobra publiczne w rolnictwie i na obszarach wiejskich (Environmental public goods in agriculture and in rural areas), Ekonomia i Środowisko (Economy and Environment) no. 1 (2015).

Malinowski, P.: Wielofunkcyjne rolnictwo jako kierunek rozwoju polskiej wsi (Multifunctional agriculture as a direction of the development of the Polish village), in: Adamowicz, M. (ed.): Zarządzanie wiedzą w Agrobiznesie w warunkach polskiego członkostwa w Unii Europejskiej (Knowledge management in Agribusiness in the conditions of Polish membership in the European Union), Prace Naukowe SGGW (Scientific Works of SGGW) no. 35 (2005).

Marsden, T., Sonnino, R.: Rural Development and the Regional State: Denying Multifunctional Agriculture in the UK, Journal of Rural Studies no. 24 (2009).

Multifunctionality: Towards an Analytical Framework. Paris: OECD, 2001.

Ramniceanu, I., Ackrill, R.: EU Rural Development Policy in the New Member States: Promoting Multifunctionality?, Journal of Rural Studies no. 23 (2007).

Renting, H., Rossini, W.A.H., Groot, J.C.J., Van der Ploeg, J.D., Laurent, C., Perraud, D., Stobbelaar, D.J., Van Ittersum, M.K.: Exploring Multifunctional Agriculture. A review of Conceptual Approaches and Prospects for an Integrative Transitional Framework, Journal of Environmental Management no. 90 (2009).

Roszkowska-Mądra, B.: Obszary wiejskie o niekorzystnych warunkach gospodarowania w aspekcie ich zrównoważonego rozwoju (Rural areas with unfavorable farming conditions in the aspect of their sustainable development, Bialystok: Wydawnictwo Uniwersytetu w Białymstoku, 2010 .

Samuelson, P.A.: The Pure Theory of Public Expenditure, The Review of Economics and Statistics no. 4 (1954).

System płatności bezpośrednich w latach 2015-2020 (Direct payments system in 2015-2020), Warszawa: MRiRW, 2015.

Wilkin, J.: Rolnictwo a społeczeństwo - ewolucja funkcji i relacji (griculture and society - the evolution of functions and relations), in: Uwarunkowania i kierunki przemian społecznogospodarczych na obszarach wiejskich (Conditions and directions of socio-economic changes in rural areas), Warszawa: IRWiR PAN, 2005.

Wilkin, J., Wielofunkcyjność rolnictwa i obszarów wiejskich (Ultifunctionality of agriculture and rural areas), in: Kłodziński, M. (ed.): Wyzwania przed obszarami wiejskimi i rolnictwem $\mathrm{w}$ perspektywie lat 2014-2020 (Hallenges in front of rural areas and agriculture in the perspective of 2014-2020), Warszawa: IRWiR PAN, 2008.

Wilkin, J.: Wielofunkcyjność rolnictwa - nowe ujęcie roli rolnictwa w gospodarce i społeczeństwie (Nactional agriculture - a new approach to the role of agriculture in the economy and society), in: Wilkin, J. (ed.): Wielofunkcyjność rolnictwa. Kierunki badań, podstawy metodologiczne i implementacje praktyczne (Multifunctionality of agriculture. Research 
directions, methodological foundations and practical implementations), Warszawa: IRWiR PAN, 2010.

Wilson, G.A.: From "Weak" to "Strong" Multifunctionality: Conceptualising Farm-level Multifunctional Transitional Pathways, Journal of Rural Studies no. 24 (2008).

Zegar, J.S.: Ekonomia wobec kwestii agrarnej (Ecomy in the face of the agrarian issue), Ekonomista (Economist) no. 6 (2010).

Zegar, J.S.: Polityka Rolna po 2013 roku (Agricultural Policy after 2013), Wieś i Rolnictwo (Village and Agriculture) no. 3 (2010).

Dyrekcja Generalna do Spraw Polityki Wewnętrznej. Jakie narzędzia europejskiej polityki rolnej sprzyjałyby dostarczaniu dóbr publicznych? (What Tools for the European Agricultural Policy to Encourage the Provision of Public Goods?) Studium 2011. www.europarl.europa.eu. 